which shows that the ordinary dark line is simply due to absorption? Put into the spectroscope, in place of the micrometer wires, an opaque diaphragm of tinfoil with two narrow slits in it at right angles to each other, thus . Put the sodium flame alone in front of the collimator slit, and by a little management one of the bright lines can be brought to shine through the vertical slit in the diaphragm, while it can also be seen as a sort of star in the horizontal one below. Now bring the lime-light behind the flame; the brightness of the vertical slit will at once considerably increase, but the horizontal slit below exhibits what was before the star, as an intensely dark spot in the midst of the bright continuous streak of colour, showing very strikingly that the apparent darkness of the line when no diaphragm is used, is a mere effect of contrast.

The paper referred to in the report as a discussion of "the want of achromatism of the ordinary achromatic object-glass," was a comparison of the secondary spectrum of a glass of the usual form and of great excellence, formerly used by me at Dartmouth College, with that of the instrument now used here. The latter is of the Gauss form, and is found to be decidedly superior in its colour corrections, while it is inferior in no other respect.

Princeton, N.Y., January 5

\section{Death of Captain Cook}

ON reading a paper reprinted from the Memoirs of the Boston Society of Natural History, vol. i. part 3 , entitled "Notes on the Volcanoes of the Hawaiian Islands," by William 'T. Brigham, A.M., I find at page 370 the following strange paragraph: "Starting from the western coast at Keálakeakua Bay-the memorable scene of Cook's punishment-the island may be described," \&c.

With writers accustomed to the correct use of the English language, the word punishment infers crime. Its use here by Mr. Brigham may be only a bilious outpouring of New England puritanism, but as it stands on the face of a grave scientific paper, it is a permanent accusation against Capt. Cook, whose reputaticn and memory as one of our greatest navigators and geographical discoverers, deserve the reverence of every Englishman. If there be any charge against Capt. Cook's reputation or moral character, which can justify the slur gratuitously cast upon his character by Mr. Brigham, in the above passage, let it be substantiated by one of his countrymen in your pages or elsewhere, but if there be no grounds on which this grave slur is justifiable, then let it not stand unchallenged by your permitting this letter to appear in the pages of NATURE.

London, January 14

ROBERT MALLET

\section{Electricity of the Blowpipe "Flame"}

I HAVE discovered what I believe to be an important fact, viz., that the blue pyrocone produced by the blowpipe from an ordinary gas-burner is not merely magnetic, but possesses polarity, for its point attracts the north pole of a compass, and repels the south pole.

Acton House, Acton, W., January I 7

\section{Suicide of Scorpion}

I MUST crave a bit of your space to beg Dr. Hutchinson (vide NATURE, vol. xxi. p. 226) to look to facts when he would refute anything based upon facts, and not trust to inferences.

My experience concerning scorpion suicide points to the fact that the "central temperature" of a circle of glowing charcoal embers (i.e. glowing when first placed on the ground in the open air, and left to die out gradually), one foot inner diameter, was never greatly in excess of the summer heat, often above $40^{\circ}$ C. in the shade in these parts, and no doubt greater at Peshawar. I keep no record of this, but I have just made a circle of glowing embers of the size of walnuts, one foot in diameter, on the kitchen floor, before the open window, suspending immediately a Casella standard in the centre and one inch from the ground, and a highly graduated Secretan, two inches from charcoal and one inch from the floor, both bulbs free, the result being :-

Centre.-After three minutes, $49^{\circ} \cdot 50$ Cent. ; at five minutes it had fallen to $46^{\circ}$, and continued to fall gradually.

Two inches from charcoal. - The heat declined gradually from $76^{\circ} \mathrm{C}$., to which it rose quickly in the beginning; general temperature of kitchen $=15^{\circ} \cdot 25$ Cent. So much for Dr. Hutchin- son's glowing inferince / which points to little short of stupidity on my part.

The fact is that so far from being cruelly scorched, the scorpions I have watched did not appear out of their element, except when they tried to escape; then they quickly receded before burning themselves, and it was after many such attempts that they " pierced their head with their sting and died," as I have stated.

As to your correspondent's theory that "the heat kills the scorpion," it does not follow from the experiments as I conducted them ; and as for his defying any one to prove that the insect dies in consequence of the self-inflicted sting, for my part I am no entomologist, and consequently am unable to make the necessary post-mortem examination. I simply state what I saw several times with a very good pair of eyes, though not, of course, "patent double-million-magnifying gas microscopes of hextra power." I now confirm the statement, and submit that if Dr. Hutchinson's patemal solicitude for his scorpions (which feeling, mind, I respect) prevents him making such cruel (?) tests, be should be content to doubt, and not pit unsound inferences against tangible evidence, much less hurl defiance at the heads of practical men.

Prov. Jaen, Linares, Spain, January 12

F. Gillman

\section{The Fertilisers of Alpine Flowers}

A FEW years ago I stated my belief in this journal that lepidoptera are far more frequent visitors and fertilisers of flowers, and that from this cause by far more flowers are adapted to crossfertilisation by lepidoptera, in the Alps than in the lowland. But it was then impossible for me to give a sufficient number of facts. Now, therefore, having continued my observations in the Alps during six summers, and being about to prepare a detailed work on "Alpine Flowers, their Fertilisation by Insects, and their Adaptations to them," I will here give a statistical statement of all visits of insects on flowers which I have observed ( 1 ) in the lowland, (2) in the Alps generally, (3) above the boundary of trees; the numbers under I being extracted from my work, "Die Befruchtung der Blumen durch Insekten, \&c." (Leipzig, I873).

Tabular Statement of the Visits of Insects to Flowers, observed by myself

\begin{tabular}{|c|c|c|c|c|c|c|}
\hline & \multicolumn{2}{|c|}{$\begin{array}{l}\text { I. In the } \\
\text { Lowland. }\end{array}$} & \multicolumn{2}{|c|}{$\begin{array}{l}\text { 2. In the Alps } \\
\text { generally. }\end{array}$} & \multicolumn{2}{|c|}{$\begin{array}{l}\text { 3. Above the } \\
\text { boundary of trees. }\end{array}$} \\
\hline & $\begin{array}{l}a . \text { Spe- } \\
\text { cies of } \\
\text { insects. }\end{array}$ & $\begin{array}{l}\text { b. Dif- } \\
\text { ferent } \\
\text { visits to } \\
\text { flowers. }\end{array}$ & $\begin{array}{l}a \text {. Spe- } \\
\text { cies of } \\
\text { insects. }\end{array}$ & $\begin{array}{l}\text { 6. Dif- } \\
\text { ferent } \\
\text { visists to } \\
\text { flowers. }\end{array}$ & $\begin{array}{c}a . \text { Spe- } \\
\text { cies of } \\
\text { insects. }\end{array}$ & $\begin{array}{l}\text { 6. Dif- } \\
\text { ferent } \\
\text { visitst to } \\
\text { flowers. }\end{array}$ \\
\hline 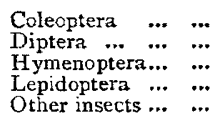 & $\begin{array}{r}129 \\
253 \\
368 \\
79 \\
14\end{array}$ & $\begin{array}{r}463 \\
1,598 \\
2,750 \\
365 \\
49\end{array}$ & $\begin{array}{r}83 \\
348 \\
183 \\
220 \\
7\end{array}$ & $\begin{array}{r}337 \\
1,856 \\
1,382 \\
2, \mathbf{1} 22 \\
15\end{array}$ & $\begin{array}{r}33 \\
210 \\
88 \\
\times 48 \\
3\end{array}$ & $\begin{array}{r}134 \\
930 \\
519 \\
\times, \mathbf{1 9 0} \\
6\end{array}$ \\
\hline Total $\quad \ldots \quad \ldots$ & $8_{43}$ & $5,23^{x}$ & $84 x$ & 5,712 & 482 & $\mathbf{2 , 7 7 9}$ \\
\hline
\end{tabular}

Hence of $\mathrm{I}, 000$ different visits to flowers (differing either by the species of flower or by the species of insect) those by-

\begin{tabular}{|c|c|c|c|c|c|c|c|}
\hline & & & & & $\begin{array}{l}\text { I. In the } \\
\text { Lowland. }\end{array}$ & $\begin{array}{l}\text { 2. In the } \\
\text { Alps gene } \\
\text { rally. }\end{array}$ & $\begin{array}{l}\text { 3. Above the } \\
\text { boundary of } \\
\text { trees. }\end{array}$ \\
\hline \multirow[t]{2}{*}{$\begin{array}{l}\text { Coleoptera are } \\
\text { Diptera } \\
\text { Hymenoptera ", } \\
\text { Lepidoptera ", } \\
\text { Other insects ", }\end{array}$} & $\begin{array}{l}\cdots \\
\cdots \\
\cdots \\
\cdots\end{array}$ & $\begin{array}{l}\ldots \\
\ldots \\
\ldots \\
\ldots\end{array}$ & $\begin{array}{l}\ldots \\
\ldots \\
\ldots \\
\ldots \\
\ldots\end{array}$ & $\begin{array}{l}\ldots \\
\ldots . \\
\ldots \\
\ldots\end{array}$ & $\begin{array}{r}89^{\circ} \cdot 66 \\
305^{\circ} \cdot 49 \\
525 \cdot 71 \\
69^{\circ} 77 \\
9^{\circ} \cdot 37\end{array}$ & $\begin{array}{r}59 \\
324.93 \\
241.95 \\
37.50 \\
2.62\end{array}$ & $\begin{array}{r}48 \cdot 22 \\
334 \cdot 65 \\
18 \cdot 26 \\
428 \cdot 3 x \\
2 \cdot 16\end{array}$ \\
\hline & & & & & $1000^{\circ} \infty$ & $1000^{\circ} \infty$ & $1000^{\circ} \infty$ \\
\hline
\end{tabular}

Lippstadt, January Io

HermanN Muller

\section{" Ideal " Matter}

IN NatURe, vol. xxi. p. 185 , you published a letter from Herr v. Nudeln, in which he alluded to the researches of Pro- 